\title{
Studies on Polyphenols and Lignin of Astronium urundeuva Wood
}

\author{
Sérgio A.L. Morais ${ }^{\mathrm{a}}{ }$, Evandro A. Nascimento ${ }^{\mathrm{a}}$, Carla R.A.A. Queiroz ${ }^{\mathrm{a}}$, \\ Dorila Piló-Veloso ${ }^{\mathrm{b}}$, and Mariza G. Drumond ${ }^{\mathrm{c}}$ \\ ${ }^{a}$ Departamento de Química, Universidade Federal de Uberlândia, \\ 38400-902 Uberlândia - MG, Brasil \\ ${ }^{\mathrm{b}}$ Departamento de Química, Universidade Federal de Minas Gerais, \\ 31270-901 Belo Horizonte - MG, Brazil \\ ${ }^{\mathrm{c}}$ Fundação Centro Tecnológico de Minas Gerais - CETEC \\ 31170-000 Belo Horizonte - Minas Gerais, Brazil
}

\begin{abstract}
Uma amostra da madeira de aroeira preta (Astronium urundeuva) moída em moinho de bolas foi extraída, sucessivamente, com benzeno, benzeno:etanol $\left(2: 1, \mathrm{vv}^{-1}\right)$, clorofórmio e água num soxhlet. A madeira extraída foi secada ao ar livre resultando o resíduo A que, em seguida, foi extraído com acetona:água $\left(9: 1, \mathrm{vv}^{-1}\right)$, também num soxhlet. Do extrato resultante foi obtida a lignina de madeira moída (MWL). Não considerando a MWL, a soma de todos os extratos alcançou 18,19\% da madeira seca. O conteúdo em lignina de Klason de $\mathbf{A}$ e o conteúdo de grupos metoxila da MWL foram $23,84 \%$ e $19,00 \%$, respectivamente. Outra amostra de $\mathbf{A}$ apresentou conteúdos em polissacarídeos de difícil e fácil hidrólise de $34,86 \%$ e 18,81\%, respectivamente. Uma Segunda amostra de madeira moída foi submetida a uma extração única com metanol, à temperatura ambiente, fornecendo o extrato metanólico $\mathbf{B}\left(23,85 \%\right.$ da madeira seca). Espectros de RMN do ${ }^{13} \mathrm{C}$ nas fases líquida e sólida indicaram que $\mathbf{B}$ está constituído fundamentalmente por proantocianidinas dos tipos profisetinidina e prorobinetinidina.
\end{abstract}

An Astronium urundeuva ball-milled wood sample was successively extracted with benzene, benzene-ethanol $\left(2: 1, \mathrm{v} / \mathrm{v}^{-1}\right)$, chloroform, and water in a soxhlet apparatus. The extracted wood was air-dried giving the residue $\mathbf{A}$ that was then treated with ketone-water (9:1), in a soxhlet apparatus. From the ketone-water extract was precipitated the milled wood lignin (MWL). With exception of MWL, the extract contents summed up $18.19 \%$ (o.d.w.). The Klason lignin content of $\mathbf{A}$ and the methoxyl content of the MWL were $23.84 \%$ and $19.00 \%$, respectively. Another sample of A gave hardly and easily hydrolysable polysaccharide contents of $34.86 \%$ and $18.81 \%$, respectively. A second sample of ball-milled wood was submitted to a single extraction with methanol, at room temperature, affording the methanol extract $\mathbf{B}\left(23.85 \%\right.$ o.d.w.). Liquid and solid state ${ }^{13} \mathrm{C}-\mathrm{NMR}$ spectroscopies indicated that $\mathbf{B}$ is mainly constituted by proanthocyanidins of profisetinidin and prorobinetidin types.

Keywords: lignin, polyphenols, Astronium urundeuva, cerrado vegetation

\section{Introduction}

Astronium urundeuva wood is well known due to its very good mechanical, biological and chemical resistance and therefore it is widely used in Brazil ${ }^{1}$. In spite of this, we could not find any systematic study on the chemical composition of this wood in the literature. In order to investigate whether there is a relationship be- tween resistance and chemical constitution, we have initiated studies to characterize the polyphenols and the lignin structure of this wood.

To obtain a lignin mostly free of polyphenol contamination, we employed the Björkmann procedure adapted for Eucalyptus grandis wood cultivated in the central region of Brazil. This wood also contains a large amount of polyphenols ${ }^{2}$.

e-mail: salemos@ufu.br 
Polyphenol studies were carried out using classical chemical techniques ${ }^{3-7}$ associated with modern high performance liquid chromatography (HPLC) $)^{8-13}$ and high resolution liquid and solid state ${ }^{13} \mathrm{C}-\mathrm{NMR}^{11,14,15}$ and FTIR spectroscopies.

This work presents the results of our studies on the Astronium urundeuva wood composition.

\section{Materials and Methods}

\section{Astronium urundeuva wood}

A stem of a thirty year old tree from Uberlândia (Triângulo Mineiro) was disk cut and air dried for 12 months.

\section{Extracts}

A ball-milled wood sample (100 g) was sequentially extracted in a soxhlet apparatus with benzene, benzene: ethanol (2:1), chloroform, and water. The isolated extracts were dried in an oven at $70{ }^{\circ} \mathrm{C}$ for $12 \mathrm{~h}$ and the residual air-dried wood powder (A) was used for MWL preparation. Another sample of ball-milled wood (50 g) was stirred with $300 \mathrm{~mL}$ of methanol in a beaker at room temperature for 24 $\mathrm{h}$ and, then, the mixture was filtered and the methanol evaporated under reduced pressure, at $40{ }^{\circ} \mathrm{C}$, yielding the extract $\mathbf{B}$.

A third sample of ball-milled wood (50 g) was submitted to an extraction with methanol: water $(80: 20)$ in a beaker at room temperature with stirring for $24 \mathrm{~h}$. Then the mixture was filtered and the methanol was evaporated under reduced pressure, at $40{ }^{\circ} \mathrm{C}$. The remaining aqueous extract $(\mathbf{C})$ was divided in four fractions and freeze-dried for its conservation. One fraction of $\mathbf{C}$ was used for total phenols analysis and another for proanthocyanidins determination; a third was extracted with ethyl ether, and the fourth fraction was used in the HPLC analysis as well as the ethereal extract.

\section{High performance liquid chromatography}

HPLC analysis was carried out in a chromatograph equipped with diode array detector and Hypersil ODS (200 $\mathrm{x} 4 \mathrm{~mm}$ i. d.) column protected by a precolumn of the same material. Two solvent mixtures were employed for elution: X: MeOH: $\mathrm{H}_{3} \mathrm{PO}_{4}$ (999:1) and Y: $\mathrm{H}_{2} \mathrm{O}: \mathrm{H}_{3} \mathrm{PO}_{4}(999: 1)$ and the gradient profile was: $0 \mathrm{~min}-40 \mathrm{~min}, 20 \%-100 \% \mathrm{X}$; $40 \mathrm{~min}-45 \mathrm{~min}, 100 \% \mathrm{X}$. The flow rate was $1 \mathrm{~mL} / \mathrm{min}$ and column oven temperature $30{ }^{\circ} \mathrm{C}$. Detection was carried out at $270 \pm 15 \mathrm{~nm}, 325 \pm 75 \mathrm{~nm}$ and $365 \pm 2 \mathrm{~nm}$. The compound identification was based on a private library of UV spectra of phenolics and flavanoids and on retention times.

\section{Total phenol contents}

Total phenol content was determined by the Folin-Ciocalteu method $^{2}$. 2,5 mL of Folin-Ciocalteu reagent (Fluka, diluted 10 times by water) and $2 \mathrm{~mL}$ of aqueous solution of sodium carbonate $\left(75 \mathrm{~g} \mathrm{~L}^{-1}\right)$ were added to $0.5 \mathrm{~mL}$ of the aqueous extract $(\mathbf{C})$, and the mixture was kept 5 min at $50{ }^{\circ} \mathrm{C}$. After cooling, absorbance was measured at $760 \mathrm{~nm}$. Aqueous solution of gallic acid $(2 \mu \mathrm{g}-40 \mu \mathrm{g})$ was used as standard. The molar absorptivity obtained in our conditions was $22.3 \times 10^{3}$.

\section{Proanthocyanidin contents}

Proanthocyanidin determination was carried out by the vanillin method ${ }^{4} .1 \mathrm{~mL}$ of the aqueous extract was mixed with $2 \mathrm{~mL}$ of a freshly prepared vanillin solution $(1 \mathrm{~g} /$ $100 \mathrm{~mL}$ of $70 \% \mathrm{H}_{2} \mathrm{SO}_{4}$ ) and maintained $15 \mathrm{~min}$ at $20^{\circ} \mathrm{C}$. The absorption was measured at $500 \mathrm{~nm}$. Calibration was performed with catechin aqueous solutions $(2 \mu \mathrm{g}-40$ $\mu \mathrm{g} \mathrm{mL}^{-1}$ ) and a molar absorbance of $34.3 \times 10^{3}$ was attained in our conditions.

\section{Anthocyanidin contents ${ }^{3-4}$}

To a reaction vial were added $6 \mathrm{~mL}$ of concentrated $\mathrm{HCl}: \mathrm{n}-\mathrm{BuOH}\left(2: 3, \mathrm{v} \mathrm{v}^{-1}\right), 1 \mathrm{~mL}$ of aqueous extract and 0.9 $\mathrm{mg}$ of $\mathrm{FeSO}_{4} \cdot 7 \mathrm{H}_{2} \mathrm{O}$. The vial was closed and left in the oven for $40 \mathrm{~min}$ at $90{ }^{\circ} \mathrm{C}$. After cooling, $0.1 \mathrm{~mL}$ of reaction mixture was dissolved in $1 \mathrm{~mL}$ of $\mathrm{MeOH}: \mathrm{H}_{2} \mathrm{O}(1: 1)$ and injected in the HPLC chromatograph.

\section{Milled wood lignin}

MWL was prepared from $\mathbf{A}$ according to Björkmann technique ${ }^{16}$ adapted by us to Eucalyptus grandis wood: the dried wood powder (100 g) was extracted in a soxhlet apparatus with ketone-water (9:1) and the organic solvent was evaporated under reduced pressure at $70{ }^{\circ} \mathrm{C}$. After that, the aqueous mixture was acidified with diluted $\mathrm{HCl}$ until $\mathrm{pH} 2$ and the precipitated lignin was filtered and washed with a small amount of water. The lignin was dried at $70^{\circ} \mathrm{C}$ for $12 \mathrm{~h}$.

\section{Easily and hardly hydrolysable polysaccharides}

The polysaccharides were determined according to the Kiesel-Semiganovski method ${ }^{17}: 4.0 \mathrm{~g}$ of $\mathbf{A}$ were refluxed with $2 \% \mathrm{HCl}$ for $3 \mathrm{~h}$ and filtered. The residue obtained was washed and dried at $105{ }^{\circ} \mathrm{C}$. The weight difference corresponds to the easily hydrolysable polysaccharides (EHP). Then, the residue was treated with $80 \% \mathrm{H}_{2} \mathrm{SO}_{4}$ for $2 \mathrm{~h}$ at room temperature and, thereafter, it was diluted up to $1 \mathrm{~L}$ and refluxed for $3 \mathrm{~h}$. The mixture was filtered and the residue was washed and dried at $105{ }^{\circ} \mathrm{C}$. The weight loss was due to the hardly hydrolysable polysaccharides (HHP).

\section{Holocellulose}

Holocellulose content was determined applying Browning procedure ${ }^{18}$ to non-extracted ball-milled wood. The obtained holocellulose still showed a pale brown color. 


\section{NMR measurements}

Solid state ${ }^{13} \mathrm{C}$-NMR spectra were recorded on a BRUKER DRX spectrometer operating at a frequency of 100.6 MHz using the pulse sequence VACP, pulse delay $0.5 \mathrm{~s}$, acquisition time $25 \mathrm{~ms}$, rotor speed $4000 \mathrm{rpm}$, and 1520 scans were collected. Liquid ${ }^{13} \mathrm{C}$-NMR spectra were recorded at the same frequency using DMSO- $\mathrm{d}_{6}$ as solvent and pulse sequence ZGPG30, power gated and angle of $30^{\circ}$ at the principal pulse; pulse delay was $1.0 \mathrm{~s}$ and $10240 \mathrm{scans}$ were collected.

\section{FTIR spectra}

They were recorded on a PERKIN-ELMER SPECTRUM 1000 spectrometer in KBr pellets.

\section{Results and Discussion}

Table 1 presents the composition of Astronium urundeuva wood. The total of substances extracted by benzene, benzene: ethanol $\left(2: 1, \mathrm{v} \mathrm{v}^{-1}\right)$, water and chloroform was very large $18.19 \%$. However, when only methanol was used as extraction solvent, at room temperature, the extract yield was still greater: $23.85 \%$. The sum of extracts, Klason lignin, EHP, plus HHP was $95.70 \%$. Holocellulose plus Klason lignin and extracts reached, however, $105.03 \%$. These discrepancies are considered normal ${ }^{18}$ and reflect the difficulties in analyzing woody materials.

In spite of Astronium urundeuva wood being very hard, its content of structural polymer cellulose is low as can be verified from the low content of hardly hydrolysable polysaccharides. However, the relatively high content of lignin and extractives is not sufficient to impart resistance to wood species against chemical and biological attacks. For instance, Eucalyptus grandis wood cultivated in the same region also contains approximately $40 \%$ of lignin plus extracts and, nevertheless, it is well known that this wood easily degrades under a tropical climate.

Table 1. Composition of Astronium urundeuva wood.

\begin{tabular}{lc}
\hline Extracts and other wood components & Percentage of dried wood \\
\hline Benzene & 1.09 \\
Ethanol-benzene & 13.68 \\
Chloroform & 0.29 \\
Aqueous & 3.13 \\
Methanol $^{\#}$ & 23.85 \\
Klason lignin from extracted wood * $^{*}$ & 23.84 \\
Hardly hydrol. carboh. (HHC) $*$ & 34.86 \\
Easily hydrol. carboh. (EHC) $*$ & 18.81 \\
Holocellulose & 63.00 \\
\hline
\end{tabular}

* Corrected for non-extracted wood; ${ }^{\#}$ single extraction.
The structure of lignin or more probably the composition of phenolics could account for the great resistance of Astronium urundeuva.

Figure 1 presents the IR spectrum of the MWL in $\mathrm{KBr}$ pellet. The band profile in the finger print region is typical of lignins ${ }^{19-20}$.

Figure 2 shows the IR spectrum of the methanolic extract B. The band distribution is characteristic of tannins $^{21}$. In addition, the great intensity of the band at 1513 $\mathrm{cm}^{-1}$ suggests that $\mathbf{B}$ is contaminated by lignin, as was the case for tannins from Eucalyptus wood ${ }^{22}$.

Due to great insolubility of the Astronium urundeuva MWL in the common NMR solvents and to the low yield of the MWL acetylation, solid state ${ }^{13} \mathrm{C}-\mathrm{NMR}$ spectroscopy was employed. Figure 3 presents the CP/MAS ${ }^{13} \mathrm{C}-\mathrm{NMR}$ spectrum of the MWL. As can be seen, the characteristic signals of guaiacyl-siringyl (G-S) lignins are present ${ }^{18,23-24}$. However, in spite of the exhaustive extraction using different solvents, MWL still contains contaminants, as can be suggested by the intense signal at $\delta 143.16$ and by the

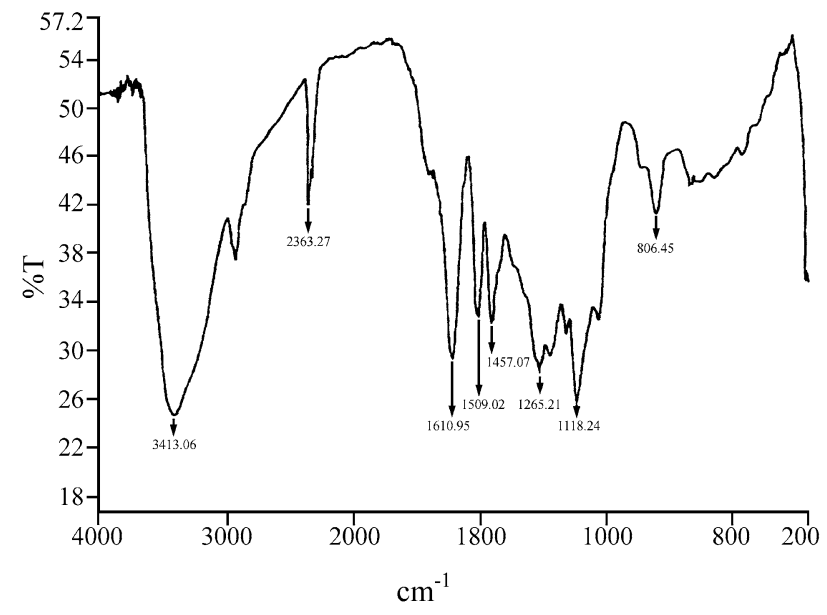

Figure 1. FTIR spectrum of the Astronium urundeuva MWL in $\mathrm{KBr}$ pellet.

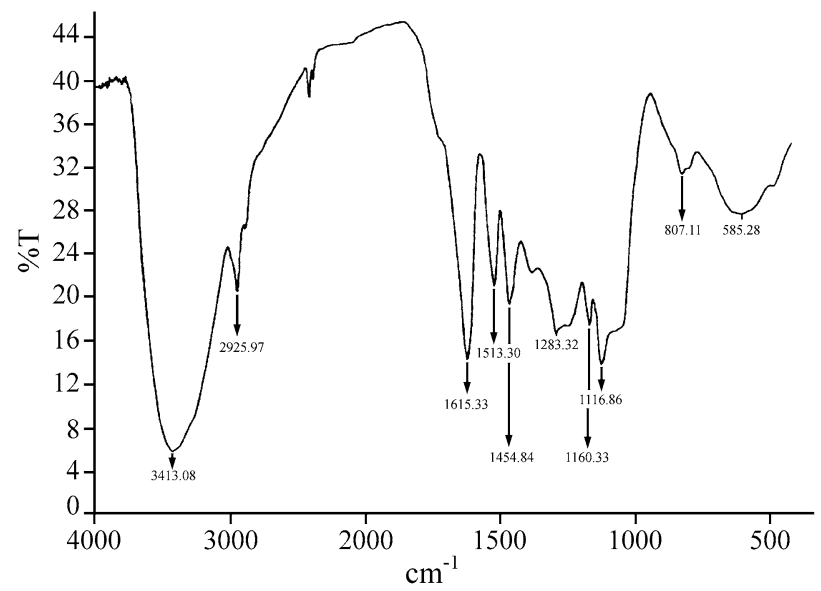

Figure 2. FTIR spectrum of the methanol extracts $(\mathbf{B})$ in $\mathrm{KBr}$ pellet. 
relatively large signals in the range $\delta 170-182$ and at $\delta$ 191.99. The signal at $\delta 181.81$ suggests the presence of $\mathrm{COOH}$ (from cinnamic acid) in the lignin structure.

Figure 4 presents the CP/MAS ${ }^{13} \mathrm{C}$-NMR spectrum of the methanolic extract $(\mathbf{B})$. With the exception of the signal at $\delta 56.47$ (due to $-\mathrm{OCH}_{3}$ ), the chemical shifts of the signals in the range $\delta 30-160$ are typical of proanthocyanidins $s^{4,11}$. In addition, Fig. 4 contains a signal at $\delta 175.97$ due to $\mathrm{C}=\mathrm{OOR}$ and $\mathrm{C}=\mathrm{OOH}$ and another two at $\delta 189.40$ and $\delta$ 199.88 that may be due to $\mathrm{C}=\mathrm{O}$ from flavanons, dihydroflavanols, ketones and aldehydes ${ }^{2,25}$.

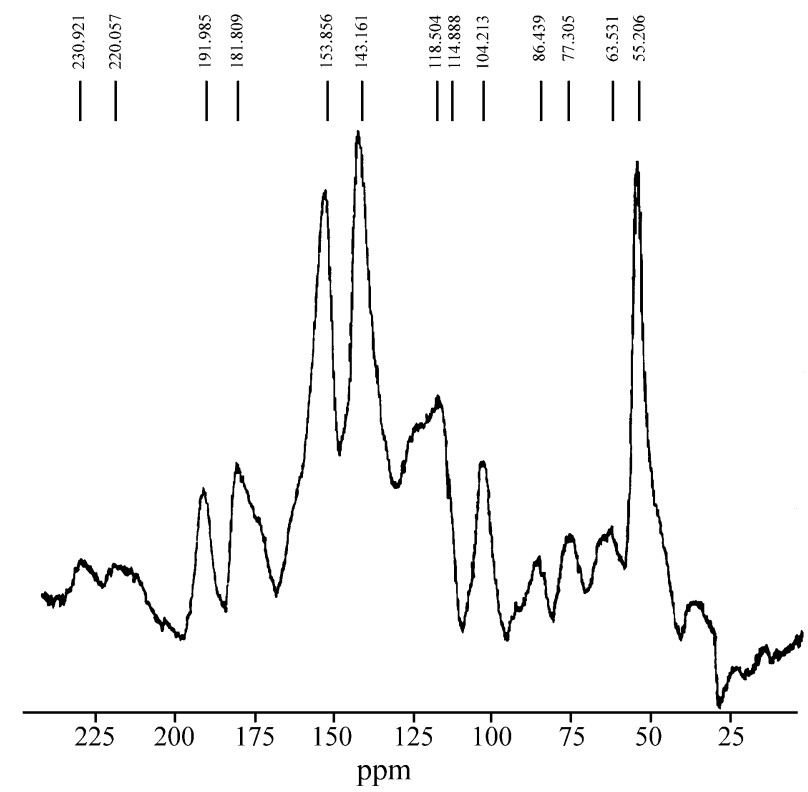

Figure 3. CP/MAS ${ }^{13} \mathrm{C}-\mathrm{NMR}$ spectrum of the Astronium urundeuva MWL.

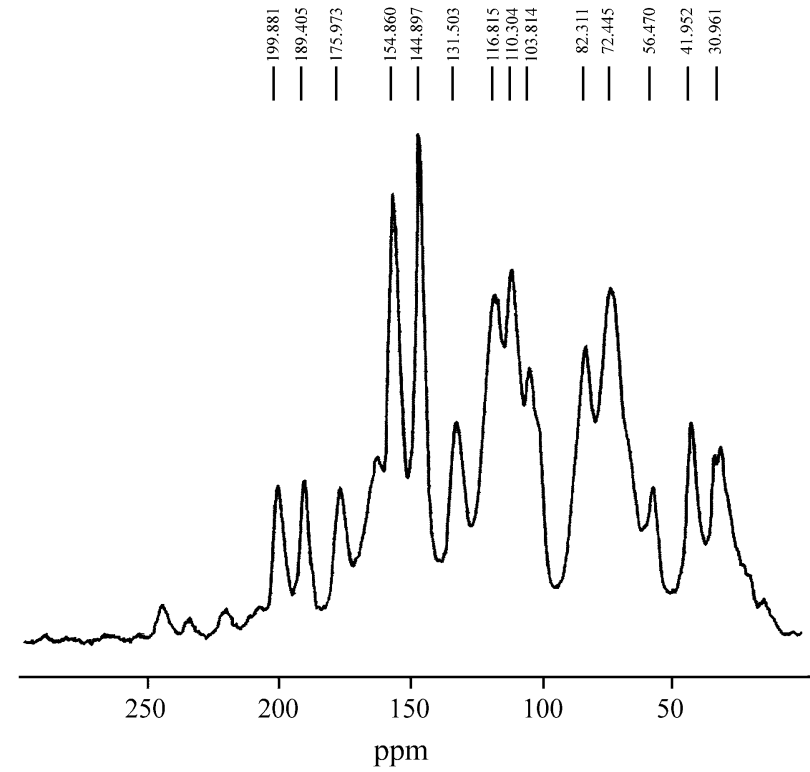

Figure 4. CP/MAS ${ }^{13} \mathrm{C}-\mathrm{NMR}$ spectrum of the methanolic extracts (B).
By comparing the spectra of Figs. 3 and 4, we can conclude that the contamination of lignin arises from tannins. On the other hand, the presence of the signal at $\delta 56.47$ in Figure 4 suggests that the tannins contain some lignin contaminant.

As lignin is slightly soluble in DMSO, we dissolved the methanolic extract in $\left(\mathrm{CD}_{3}\right)_{2} \mathrm{CO}$, filtered the mixture and recorded the ${ }^{13} \mathrm{C}$-NMR spectrum of the resulting solution (Fig. 5). This spectrum is then more representative of $\mathbf{B}$.

Considering that condensed tannins (proanthocyanidins) are polymers constituted by the flavan-3-ol monomeric units shown in Fig. 6, the most outstanding characteristic of Fig. 5 is the chemical shift assigned to carbon- 8 of the A ring at $\delta 102.82^{4}$. This chemical shift indicates that the hydroxylation pattern in the A ring is of resorcinol type, i.e., only carbon-7 is hydroxylated. This finding is very important because it eliminates other monomeric units with the exception of fisetinidol and robinetinidol (Fig. 6). In order to characterize whether fisetinidol or robinetinidol or both monomeric units are present in the extract $\mathbf{B}$, the reported characteristic ${ }^{13} \mathrm{C}-\mathrm{NMR}$ chemical shifts for B-ring oxidation patterns ${ }^{4,15}$ were used to further analyze Fig. 5. Table 2 presents the reported ${ }^{13} \mathrm{C}$-NMR chemical shifts and those obtained from Fig. 5 . The found and reported data are in good agreement and so Table 2 suggests that fisetidinol and robinetinidol polymers may be the main components of the studied condensed tannins.

Figure 7 presents the HPLC chromatogram of the ethereal extract obtained from the aqueous extract. Fisetin is the main component; gallic and ellagic acids were also detected; minor concentrations of compounds showing UV

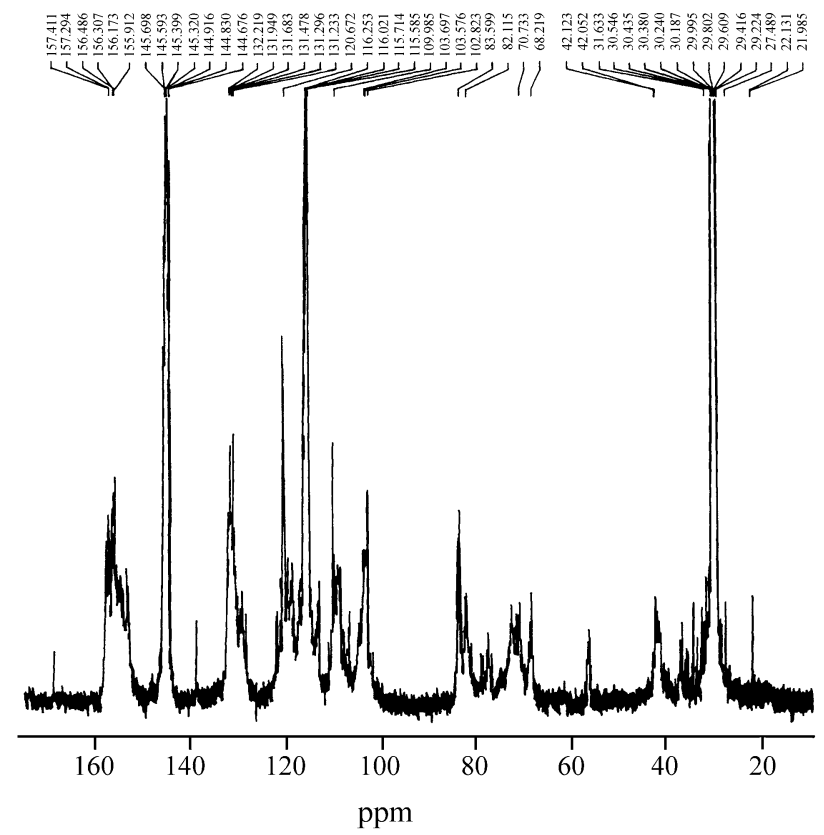

Figure 5. ${ }^{13} \mathrm{C}-\mathrm{NMR}$ spectrum of the methanol extract $(\mathbf{B})$ in $\left(\mathrm{CD}_{3}\right)_{2} \mathrm{CO}$. 
Table 2. ${ }^{13} \mathrm{C}$-NMR chemical shifts for B-ring hydroxylation patterns.

\begin{tabular}{|c|c|c|c|c|c|c|c|c|c|c|c|}
\hline \multirow{3}{*}{$\begin{array}{l}\text { B-ring } \\
\text { 3',4'-dihy-droxy }\end{array}$} & \multicolumn{11}{|c|}{ Carbon atom } \\
\hline & \multicolumn{2}{|c|}{1 ' } & \multicolumn{2}{|c|}{$2^{\prime}$} & \multicolumn{2}{|c|}{$3^{\prime}$} & \multicolumn{2}{|c|}{$4^{\prime}$} & \multicolumn{2}{|c|}{5,} & $6{ }^{\prime}$ \\
\hline & $131.5^{\mathrm{b}}$ & (132) & $115.7^{\mathrm{b}}$ & (115) & $144.8^{\mathrm{b}}$ & (145) & $144.8^{\mathrm{b}}$ & (145) & $116.0^{\mathrm{b}}$ & (116) & 120.7 \\
\hline 3',4',5'-tri-hydroxy & $131.5^{\mathrm{b}}$ & (132) & $108.0^{\mathrm{b}}$ & (108) & $145.5^{\mathrm{b}}$ & (146) & 132.2 & (133) & $145.6^{\mathrm{b}}$ & $(146)$ & $108.0^{\mathrm{b}}$ \\
\hline
\end{tabular}

${ }^{\mathrm{a}} \mathrm{In}\left(\mathrm{CD}_{3}\right)_{2} \mathrm{CO}$; reported ${ }^{13} \mathrm{C}-\mathrm{NMR}$ chemical shifts ${ }^{4,15}$ are given in parentheses.

${ }^{\mathrm{b}}$ Average of various values obtained from Fig. 5 .

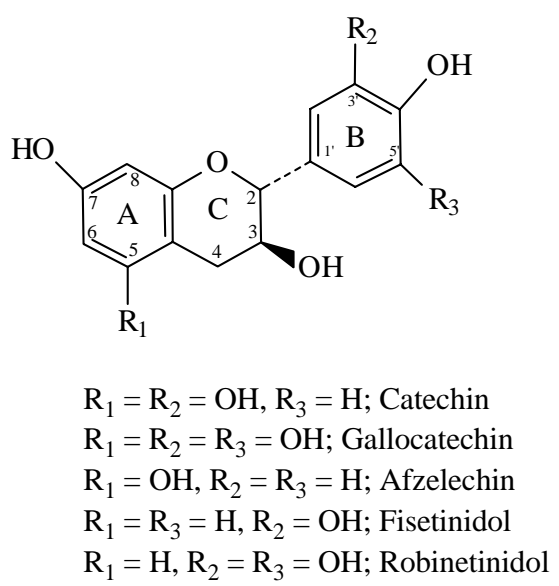

Figure 6. Proanthocyanidin precursores.

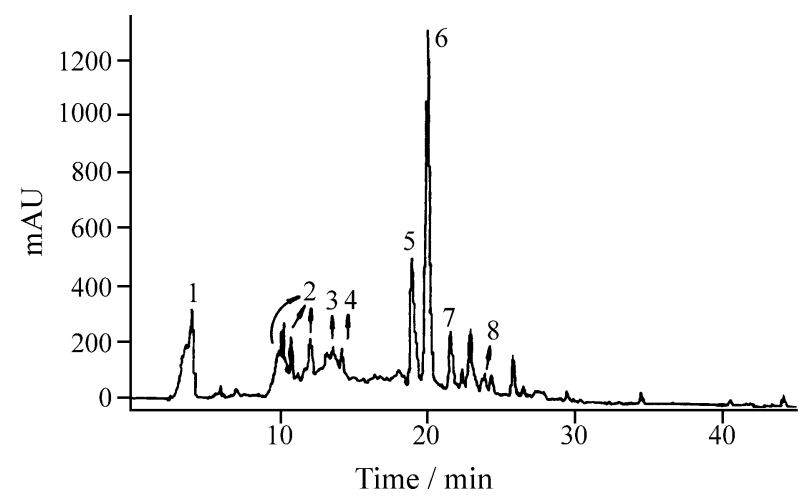

Figure 7. HPLC chromatogram of the ethereal extract: gallic acid (1), flavanons (2), hydroxyacid (3), ellagic acid (4), fisetin (5), ellagitannins (6), and flavanol (7).

spectral characteristics of flavanons, flavanols and ellagitannins were observed. The presence of fisetin constitutes further evidence of the occurrence of profisetinidins in Astronium urundeuva wood.

Figure 8 presents the HPLC chromatogram of the aqueous extract after ether extraction. Gallic acid and a broad band composed of many proanthocyanidins could be detected.

In order to detect other monomeric compounds that constitute the polymeric structure of the proanthocyanidins, we then tried cleaving the polymer bonds with $\mathrm{HCl} / \mathrm{n}$-butanol. In spite of strong conditions, the proanthocyanidins of the aqueous extract were not degraded, as can be shown<smiles>[R]c1cc([C]2Oc3cc(O)cc(O)c3C[C@H]2O)cc([R])c1O</smiles>

$$
\begin{aligned}
& \mathrm{R}_{1}=\mathrm{OH}, \mathrm{R}_{2}=\mathrm{H} \text {; Epicatechin } \\
& \mathrm{R}_{1}=\mathrm{R}_{2}=\mathrm{H} \text {; Epiafzelechin } \\
& \mathrm{R}_{1}=\mathrm{R}_{2}=\mathrm{OH} \text {; Epigallocatechin }
\end{aligned}
$$

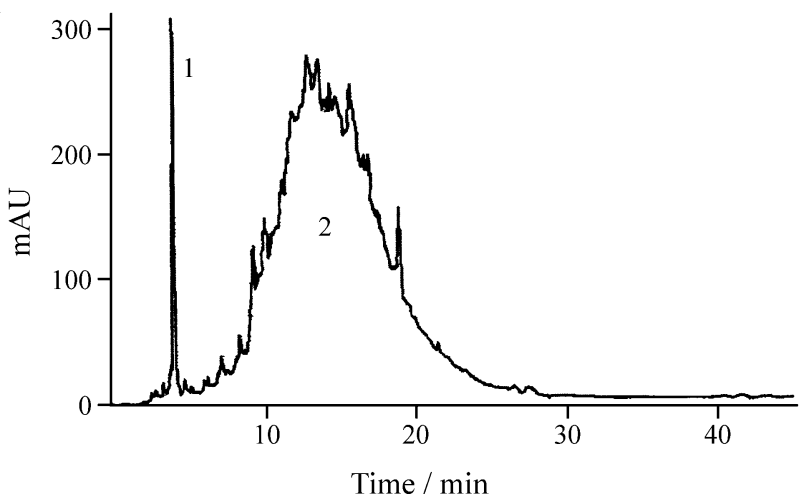

Figure 8. HPLC chromatogram of the aqueous extract: gallic acid (1), and proanthocyanidins (2).

by the HPLC chromatogram of the reaction extract (Fig. 9). Only gallic acid, n-butylgallate (resulting from gallic acid and n-butanol) and proanthocyanidins were detected.

At this point, it is interesting to compare the elemental analysis of the methanolic extract and lignin: C: $56.84 \%$; H: $5.25 \%$; $\mathrm{N}: 0.66 \%$; O: $37.25 \%$ and C: $59.50 \%$; H: $4.38 \%$; $\mathrm{N}: 0.77 \%$; O: $35.35 \%$, respectively. The high oxygen content in the methanol extract may indicate that this material suffered oxidation during the long exposure to air in the drying process.

Using the methoxyl content found for lignin (19.0\%), the calculated $\mathrm{C}_{9}$-unit formula is $\mathrm{C}_{9} \mathrm{H}_{5.21} \mathrm{O}_{3.31}\left(\mathrm{OCH}_{3}\right)_{1.25}$ which also indicates a relatively high oxygen content ${ }^{26}$ probably due to contamination by tannins. 


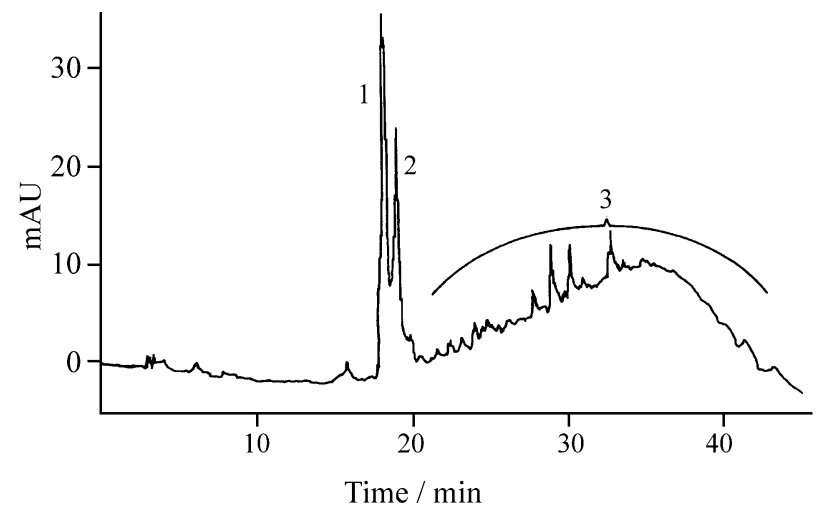

Figure 9. HPLC chromatogram of the mixture resulting from the reaction of aqueous extract with $\mathrm{HCl} / \mathrm{n}$-butanol: ellagic acid (1), n-butylgallate (2), and proanthocyanidins (3).

Finally, the measured phenolic $\mathrm{OH}-$ content in MWL $(3.2 \%)$ is too high for lignins and this result is also in good agreement with the supposed contamination by the oxidized tannins.

Regarding the classical chemical assays, the aqueous extract presented $100.7 \mathrm{mg}$ of gallic acid equivalents and $12.9 \mathrm{mg}$ of catechin equivalents for $1 \mathrm{~g}$ of extracted milled wood (o.d.w.). These results are much higher than those reported in the literature for Eucalyptus species ${ }^{2,27}$ and they confirm once more that Astronium urundeuva wood contains a large amount of tannins.

\section{Conclusions}

Astronium urundeuva wood contains a large amount of extracts, which are constituted mainly by proanthocyanidins, probably of profisetinidin and prorobinetinidin types.

The milled wood lignin could not be isolated in pure form even when extracting the milled wood sequentially with benzene, benzene:ethanol, chloroform, and water before the final extraction with ketone:water (9:1). Some contamination by tannins still remains. This suggests a strong association between lignin and tannins.

The association of lignin and tannins and/or the presence of profisetinidins and prorobinetinidins could account for the great resistance of Astronium urundeuva wood regarding chemical and biological degradation.

\section{Acknowledgments}

Financial support from CNPq and FAPEMIG are grateful acknowledged; Dr. M.C. García Vallejo and collaborators (CIFOR - INIA - Madrid) are also acknowledged for the HPLC analyses and discussions.

\section{References}

1. Haase, R.; Hirooka, R.Y. Flora 1998, 193, 141.

2.Piló-Veloso, D.; Nascimento E.A.; Morais, S.A.L. Química Nova 1993, 16, 435.
3. Scalbert, A.; Monties, B.; Janin, J.G. Agric. Food Chem. 1989, 37, 1324.

4. Porter, L.J. Tannins in Methods in Plant Biochemistry, v. 1, Academic Press, New York, p. 200, 1989.

5. Inoue, K.H.; Hagerman, A.E. Anal. Biochem. 1988, 169, 363.

6. Roux, D.G.; Miller, T.H.; Maihs, A.E. J. Am. Leather Chem. Assoc. 1961, 56, 362.

7. Fechtal, M.; Riedel, B. Holzforschung 1991, 45, 269.

8. Charrier, B.; Marques, M.; Haluk, J. Holzforschung 1992, 46, 87.

9. Yazaki, Y.P.; Collins, J.; Iwashina, T. Holzforschung 1993, 47, 412.

10. Sjöstrom, J.; Badenlid, R.; Norborg, M.A. Holzforschung 1993, 47, 446.

11. Nascimento, E.A. Morais, S.A.L.; Cadahía, E.; Conde E.; Fernández De Simón, B.; García-Vallejo, M.C. Ciência \& Engenharia 1996, 2, 13.

12. Cadahía, E.; Conde E.; Fernández De Simón, B.; García-Vallejo, M.C. Holzforschung 1997, 51, 119.

13. Cadahía, E.; Conde E.; Fernández De Simón, B.; García-Vallejo, M.C. Holzforschung 1997, 51, 125.

14. Kolodziej, H.; Ferreira, D.; Roux, D.G. J. Chem. Soc., Perkin Trans. I 1984, 343.

15. Steynberg, P.J.; Steynberg, P.J.; Brandt, E.V.; Ferreira, D.; Hemingway, R.W. J. Chem. Soc., Perkin Trans. I 1997, 1943.

16. Björkman, A. Svensk Papperstidn 1956, 59, 477.

17. Charkov, V.I.; Sapotnicki, S.A.; Dmitrieva, O.P.; Tumanov, I.S. Technology of Chemical Industries For. Ind. Ed; Moscow, 1973.

18. Browning, B.L. Methods of Wood Chemistry; v. 2, Interscience Publishers; New York, London, p. 387, 1967.

19. Vázquez, G.; Antorrena G.; González J.; Freire S. Holzforschung 1997, 51, 158.

20. Abreu, H.S. Química Nova 1997, 20, 592.

21. Foo, L.Y. Phytochemistry 1981, 20, 1397.

22. Nascimento, E.A.; Morais, S.A.L.; Veloso, D.P. $J$. Braz. Chem. Soc. 1991, 2, 129.

23. Morgan, K.R.; Newman, R.H. Appita 1987, 40, 450.

24. Hawkes, G.E.; Smith, C.Z.; Utley, J.H.P.; Vargas, R.R.; Viertler, H. Holzforschung 1993, 47, 302.

25. Alderete, J.B.; Fardim, P., Angelo, R.; Fujiwara, F., Durán, N. In Proc. Fifth European Workshop on Lignocellulosics and Pulp, Aveiro, Portugal, p. 93, 1998.

26. Freudenberg, K; Neish, A.C. Constitution and Biosynthesis of Lignins; Spring Verlag; Berlin, p. 47, 1968.

27. Conde E.; Fernández De Simón, B.; García-Vallejo, M.C. Holzforschung 1995, 49, 411. 